\title{
Coping with Christian Pictorial Sources: What Did Jewish Miniaturists Not Paint?
}

\author{
By Katrin Kogman-Appel
}

When Jewish miniaturists of the thirteenth century began to adorn manuscripts with narrative depictions, they turned to Christian pictorial sources for models and ideas. Those contacts were made possible by the establishment of urban lay workshops during that period in the towns of Europe. In their basic iconography and compositional outline Jewish narrative cycles often reveal much similarity to Christian parallels, and the character of specific models has been dealt with in previous research. ${ }^{1}$ This is especially true for the continuous biblical cycles that were created by Catalan Jewish illuminators of the fourteenth century for the adornment of manuscripts of the Passover Haggadah. However, Ashkenazi biblical iconography is also characterized by various degrees of closeness to Christian pictorial sources. The examination of the cycles reveals a great variety of pictorial models from different areas and periods. The Catalan cycles, for example, use Spanish sources only to a very small extent, whereas Italian and French models play a major role. ${ }^{2}$ The same is true of Ashkenazi examples of Old Testament iconography, which reveal very little relationship to contemporary German Old Testament cycles and rely instead on more remote sources. ${ }^{3}$

The biblical cycles of illuminated Hebrew manuscripts had then to be translated into a Jewish pictorial language. One way to deal with this translation was the interpolation of iconographic elements inspired by rabbinic biblical commentary, interwoven with the basic compositions borrowed from Christian models.

A short version of this paper was presented at the annual conference of the College Art Association on February 11, 1999, in Los Angeles. I wish to thank Harvey Stahl, the chair of the session on medieval art, for his comments. I am grateful to Daniel Lasker for his numerous comments and suggestions concerning the polemical texts. Catherine Logan is to be thanked for editing the English version of the text. This article is part of a project on biblical cycles in Hebrew illuminated manuscripts, supported by the Israeli Science Foundation, founded by the Israeli Academy of Sciences and Humanities.

' For example, in Bezalel Narkiss, The Golden Haggadah: A Fourteenth Century Illuminated Hebrew Manuscript in the British Museum. Facsimile and Introduction (London, 1970); and Gabrielle Sed-Rajna, The Hebrew Bible in Medieval Illuminated Manuscripts, trans. Josephine Bacon (New York, 1987).

${ }^{2}$ Katrin Kogman-Appel, "Die Modelle des Exoduszyklus der Goldenen Haggada (London, British Library, Add. 27210)," in Clemens Thoma et al., eds., Judentum-Ausblicke und Einsichten: Festgabe fïr Kurt Schubert zum siebzigsten Geburtstag (Frankfurt am Main, 1993), pp. 269-300; eadem, "Der Exoduszyklus der Sarajevo-Haggada: Bemerkungen zur Arbeitsweise spätmittelalterlicher jüdischer Illuminatoren und ihrem Umgang mit Vorlagen," Gesta 35/2 (1996), 111-27; and eadem, "The Picture Cycles of the Rylands Haggadah and the So-Called Brother Haggadah and Their Relation to the Western Tradition of Old Testament Illustration," Bulletin of the Jobn Rylands University Library 79/ 2 (1997), 3-20.

${ }^{3}$ See, for example, Katrin Kogman-Appel, Die zweite Nürnberger und die Jehuda Haggada: Jüdische Illuminatoren zwischen Tradition und Fortschritt (Frankfurt am Main, 1999), pp. 127-221. 
Whereas earlier studies frequently searched for late-antique roots of these interpolations in the form of hypothetical ancient illuminated Jewish manuscripts, ${ }^{4} \mathrm{I}$ have shown elsewhere that it is more likely that the rabbinic elements were created and invented ad hoc by the medieval Jewish miniaturists. The lack of ancient parallels and the lack of contemporary Jewish parallels make the notion of continuity from late antiquity to the late Middle Ages problematic. Many of the midrashic interpolations remain unparalleled in late-antique Jewish or Christian art, as well as in medieval Hebrew manuscripts. Therefore I believe that they originated as part of the effort to translate Christian pictorial sources into a Jewish idiom. ${ }^{5}$ It is through these midrashic interpolations that the compositions borrowed from Christian art could become a Jewish medium for visual communication of rabbinic Bible interpretation. Because of this involvement of rabbinic thought in the iconography of biblical picture cycles, the latter could be transformed and become an important medium of visual communication, meaningful in the eyes of the Jewish spectator.

There still remains another problem: whereas the meaning of the narrative parts of the Hebrew Bible or a Jewish biblical picture cycle was primarily historicalfor example, as an account of the story of the chosen people and the Lord's intervention in history - that of the Christian Old Testament was primarily typological. Not only were the Prophets' sayings interpreted as announcing the coming of Jesus Christ, but Old Testament figures and events were regarded as types of New Testament events or prefigurations of Christ, his mother, his disciples, and others. This Christological interpretation of the Old Testament's narrative parts was the subject of frequent patristic commentaries on the Bible and had an immense impact on the development of Christian Old Testament iconography. The high-medieval typological programs, such as Nicholas of Verdun's altarpiece in the abbey of Klosterneuburg near Vienna (1180), ${ }^{6}$ the various copies of the Bible moralisée, ${ }^{7}$ the Biblia pauperum ${ }^{8}$ and the Speculum humanae salvationis, ${ }^{9}$ express this understanding of the Old Testament in its clearest form. But even the more historically oriented cycles were also driven by the perception that the primary function of the Old Testament was to foreshadow the coming and life of Christ.

\footnotetext{
${ }^{4}$ Ursula and Kurt Schubert, Jüdische Buchkunst, 2 vols. (Graz, 1983-92), p. 126; Narkiss, Golden Haggadah, pp. 43-61; Sed-Rajna, Hebrew Bible, p. 8; eadem, "Further Thoughts on an Early Illustrated Pentateuch," Journal of Jewish Art 10 (1984), 29-31; and eadem, "Haggadah and Aggadah: Reconsidering the Origins of the Biblical Illustrations in Medieval Hebrew Manuscripts," in Doula Mouriki and Christopher Moss, eds., Byzantine East, Latin West: Art-Historical Studies in Honor of Kurt Weitzmann (Princeton, N.J., 1995), p. 420.

${ }^{s}$ Katrin Kogman-Appel, "The Sephardic Picture Cycles and the Rabbinic Tradition: Continuity and Innovation in Jewish Iconography,” Zeitschrift für Kunstgeschichte 60/4 (1997), 451-81.

${ }^{6}$ Helmut Buschhausen, Der Verduner Altar: Das Emailwerk des Nikolaus von Verdun im Stift Klosterneuburg (Vienna, 1982).

${ }^{7}$ For example, Vienna, Österreichische Nationalbibliothek, Cod. 2554; see Rainer Haussherr, Bible moralisée: Faksimile-Ausgabe im Originalformat des Cod. Vind. 2554 der Österreichischen Nationalbibliothek (Graz, 1973), new ed. by Gerald B. Guest (London, 1995). On the Bibles moralisées see also John Lowden, The Making of the Bibles moralisées (University Park, Pa., 2000).

${ }^{8}$ Avril Henry, Biblia pauperum (Ithaca, N.Y., 1987).

${ }^{9}$ Adrian Wilson and Joyce L. Wilson, A Medieval Mirror: Speculum humanae salvationis, 13241500 (Berkeley, Calif., 1984).
} 
This view of Israel's history as expressed in art was a further challenge to Jewish illuminators in processing Christian pictorial sources. They faced numerous elements with particular Christological meaning and detail, which reflected Christian dogma and specific beliefs. How the Jewish miniaturists coped with the Christological contents of iconographic themes borrowed from Christian pictorial sources is the subject of the present study. On the premise that Christological hints, allusions, and iconographic details were avoided-as will be shown in the following pages - the consequent question is, How did Jewish artists know what details to avoid? How and to what extent did they become familiar with the Christian interpretation of the Bible? For example, Isaac carrying wood arranged crosswise on his shoulders on the way to Mount Moriah was an obvious hint that he was understood as a prefiguration of Christ carrying the cross to Golgotha (Fig. 8). But Christian pictorial language was not always so unambiguously clear to the outsider, nor were Old Testament scenes always juxtaposed with New Testament subjects to make the connections obvious. Thus the Christological undertone of an event was not always immediately apparent in scenes that could be perceived as renderings of a mere historical context.

Jewish illuminators had a wide knowledge of the Midrash, but it is not to be assumed that they were familiar with Christian texts in Latin. ${ }^{10}$ Their sources of knowledge must have been of a different kind. The character of Jewish-Christian relations since the late twelfth century brought forth a category of books usually referred to as polemical writings, although the borderline between polemics, disputations, and apologetics is not clearly defined. ${ }^{11}$ A series of texts by Jewish scholars, primarily from Provence and Iberia, deal with a variety of themes in the context of Jewish-Christian relationships. ${ }^{12}$ Some of these include Christian accusations against Jews, such as moneylending at interest, as well as Christian dogmas, such as the Trinity and the Incarnation. In most texts, finally, Christian interpretations of the Old Testament were discussed. The main aim of anti-Jewish agitation during the high and the late Middle Ages was conversion. The church engaged in various means of "persuasion," the most violent of which was forced baptism. Others included forced delivery of sermons during synagogue services and public disputations between clerics-often Jewish apostates-and Jewish scholars. One such disputation took place in 1263 in Barcelona and was characterized by the appearance of Moses ben Nahman, known as Nahmanides; another took place in 1413-14 in Tortosa. Christian and Jewish accounts document the

\footnotetext{
${ }^{10}$ Some scholars assume that Jews traditionally were reluctant to use the Latin language; see Thomas Glick, Islamic and Christian Spain in the Early Middle Ages (Princeton, N.J., 1979), p. 258. In the various translation projects of the twelfth and thirteenth centuries, typical of the atmosphere of cultural interchange in medieval Spain, Jewish scholars usually produced vernacular versions of Arabic texts, which were then translated into Latin by Christian clerics; ibid., pp. 257-58.

${ }^{11}$ Hanne Trautner-Kromann, Shield and Sword: Jewish Polemics against Christianity and the Christians in France and Spain from 1100-1500 (Tübingen, 1993), pp. 2-3.

${ }^{12}$ Samuel Krauss, The Jewish-Christian Controversy from the Earliest Times to 1789, Edited and Revised by William Horbury (Tübingen, 1995), contains an extensive list of Jewish polemicists and their texts, pp. 201-61.
} 
course of these disputations from different points of view. ${ }^{13}$ Other types of texts contain fictive disputations meant as guidelines for future discussions, such as the Sefer haBrit by Joseph Kimhi, ${ }^{14}$ written around 1170 at the request of a student to serve as an aid in discussions with Christians. ${ }^{15}$ There were also letters, such as one by Profyat Duran, ${ }^{16}$ and biblical commentaries.

It is the biblical commentaries that concern me most in the present context. Whereas most polemical commentaries concentrate on the Prophets and the Psalms, a few focus upon typological themes in the historical books of the Bible. In the twelfth century, for example, Jacob ben Reuben in southern France or northern Spain produced an account of a dispute on the Bible between a Christian and a Jew; whether the dispute was fictive, like Kimhi's, or real we do not know. ${ }^{17}$ Since his argumentation is philosophically oriented, material dealing with narrative aspects is scarce and confined to the question of the Trinity. ${ }^{18}$ Jacob explicitly states in his introduction that he used to study with a priest in his town and that the latter was his source of knowledge. ${ }^{19}$ Yehuda Rosenthal, the modern editor of the text, believed Jacob ben Reuben to be of Spanish origin, a refugee from Almohad persecutions who settled in Gascogne. ${ }^{20}$ In the middle of the thirteenth century, Joseph ben Nathan Official, who lived in Sens and, like his father, served as a financial adviser to the archbishop, wrote a text entitled Sefer Joseph haMeqane [The Book of Joseph the Zealous]. ${ }^{21}$ Instead of grouping the various themes that usually came up in Jewish-Christian disputes, he interpreted the Bible following the chronology of the events, while concentrating on the typological claims of Christian commentaries. Joseph was a student of Jehiel of Paris, the main Jewish disputant at the Talmud trial in Paris in 1240, and apparently had written the Hebrew account of it. The Sefer Joseph haMeqane, however, is not a report of a disputation, whether actual or fictive, but rather a general guide for Jews in coping with Christian dogma and interpretations of the Old Testament. Shortly thereafter an anonymous text was written in Germany, partly based on

\footnotetext{
${ }^{13}$ Hans-Georg von Mutius, Die christlich-jüdische Zwangsdisputation zu Barcelona (Frankfurt am Main, 1982); Hyam Maccoby, Judaism on Trial: Jewish-Christian Disputations in the Middle Ages (London, 1982); Robert Chazan, Daggers of Faith: Thirteenth-Century Christian Missionizing and Jewish Response (Berkeley, Calif., 1989); and idem, Barcelona and Beyond: The Disputation of 1263 and Its Aftermath (Berkeley, Calif., 1992).

${ }^{14}$ Ed. Frank Ephraim Talmage (Jerusalem, 1974); for an English translation see Frank Ephraim Talmage, trans., The Book of the Covenant (Toronto, 1972).

${ }^{15}$ Ed. Talmage, p. 21. However, Talmage is not certain whether the book was written as a protocol of an actual disputation or as a fictive account; ibid., p. 14. See also Trautner-Kromann, Shield and Sword, pp. 61-65.

${ }^{16}$ Al Tehi ka-Avotekha, ed. Frank Ephraim Talmage, in Divre Pulmus leProfyat Duran (Jerusalem, 1981); and Krauss, Controversy, p. 210.

${ }^{17}$ Robert Chazan, "The Christian Position in Jacob ben Reuben's Milhamot Ha-Shem," in Jacob Neusner, Ernest S. Frerichs, and Nahum M. Sarna, eds., From Ancient Israel to Modern Judaism: Intellect in Quest of Understanding. Essays in Honor of Marvin Fox, 2 (Atlanta, 1989), p. 160.

${ }^{18} \mathrm{Jacob}$ ben Reuben, Milhamot haShem, ed. Yehuda Rosenthal (Jerusalem, 1963), pp. 23-62.

${ }^{19}$ Ibid., pp. 3-6.

${ }^{20}$ Ibid., pp. ix-x.

${ }^{21}$ Ed. Yehuda Rosenthal (Jerusalem, 1970); for more information see Trautner-Kromann, Shield and Sword, pp. 90-94; and Krauss, Controversy, p. 218.
} 
Joseph Official's book. Known as Sefer Nitzahon Yashan, it, like its predecessor, follows the biblical text verse by verse, picking verses that had been interpreted typologically. ${ }^{22}$ As Daniel Lasker has pointed out, "the usefulness of exegetical arguments was . . . limited" in actual Christian-Jewish disputations because of the lack of "clear-cut rules of exegesis" on both sides and of "criteria for determining the correct interpretation." 23 This circumstance may explain the comparatively small number of books challenging Christian typological interpretations of the Bible, although exegetical argumentation is dominant in the entire genre.

The purpose of such texts was not merely polemical, a refutation of Christian doctrines or of anti-Jewish accusations, but rather a means of coping with Christian pressure to cause Jews to convert. Research into Jewish polemical writings has revealed that the target group of such texts were Jews, not Christians or baptized Jews. They were addressed to Jews whose faith was to be strengthened against Christian pressure. They were not mere aids in disputation but textbooks on how Jews could maintain their faith and remain true to their beliefs. ${ }^{24}$ Solomon ibn Adret, a student of Nahmanides and author of a polemical commentary on rabbinic biblical interpretations during the second half of the thirteenth century, states explicitly that his intention was "to strengthen [his] brothers in faith." 25 Addressed to the ordinary Jew, as well as scholars, these texts refuted Christian claims that the Old Testament foreshadowed the New and that the Prophets spoke about Jesus, and they explained Christian doctrines as irrational and illogical. Many of these texts concentrate on a refutation of the Trinity, the Incarnation, Transubstantiation, and the virgin birth in philosophical terms, and their arguments have been discussed exhaustively by Daniel Lasker. ${ }^{26}$ Hanne Trautner-Kromann, who studied the texts recently, has provided a survey of the scholars who dealt with polemics. In her analysis of samples of texts, she concentrated on four subjects: the accusation of moneylending at interest, Christian morals, Christian doctrines, and the theme of verus Israel. ${ }^{27}$ Polemics in biblical commentaries have been less exhaustively studied, ${ }^{28}$ the emphasis usually being put on the books of the Prophets and the Psalms. No study has been entirely devoted to Jewish polemics dealing with Christian typology. ${ }^{29}$

${ }^{22}$ David Berger, The Jewish-Christian Debate in the High Middle Ages: A Critical Edition of the Nizzahon vetus (Philadelphia, 1979), Hebrew text with English translation. For further information, see Berger's introduction; Trautner-Kromann, Shield and Sword, pp. 102-4; and Krauss, Controversy, p. 246.

${ }^{23}$ Daniel Lasker, Jewish Philosophical Polemics against Christianity in the Middle Ages (New York, 1977), p. 7.

${ }^{24}$ Erwin J. R. Rosenthal, “Anti-Christian Polemic in Medieval Bible Commentaries," Journal of Jewish Studies 11 (1960), 115-35; Lasker, Philosophical Polemics; Robert Chazan, "Polemical Themes in the Milhemet Mizvah," in Gilbert Dahan, ed., Les Juifs au regard de l'histoire: Mélanges en l'honneur de Bernhard Blumenkranz (Paris, 1985), pp. 169-84; idem, Daggers; and recently also Trautner-Kromann, Shield and Sword.

${ }^{25}$ Perushei Aggadot, ed. Joseph Perles (Breslau, 1863), p. 25; see also Trautner-Kromann, Shield and Sword, p. 133.

${ }^{26}$ Lasker, Philosophical Polemics.

${ }^{27}$ Trautner-Kromann, Shield and Sword.

${ }^{28}$ Rosenthal, "Anti-Christian Polemic"; and Hanne Trautner-Kromann, "Jewish Polemics against Christianity and the Christians in Northern and Southern France from 1100-1300," Nordisk Judaistik/Scandinavian Jewish Studies 7/2 (1986), 71-83.

${ }^{29}$ A few texts have been analyzed in Trautner-Kromann, Shield and Sword. 
In dealing with a "translation" of Christian visual sources into a Jewish pictorial language, Jewish miniaturists faced Christian dogma and doctrines in a visual medium within the general atmosphere of Christian pressure, conversion, and forced baptism. They must have been well aware of the danger of themselves becoming organs of Christian doctrine and Bible interpretation. An examination of those iconographic elements that were avoided by Jewish miniaturists reveals that many of them were conversant with the polemical writings produced between the twelfth and fifteenth centuries. The Jewish picture cycles date from the period between the thirteenth and fifteenth centuries: they started when pictorial sources became accessible in urban Christian workshops, and they ceased during the fifteenth century, when most European Jewish communities suffered expulsion.

In the following pages I shall examine biblical themes in Jewish iconography, compare them with Christian parallels, and point out those elements that hint at specific Christological-typological contexts. I shall then consult the polemical texts as sources of knowledge about the Christological background. This approach does not necessarily presume that the actual text was consulted in every single case. Various other channels of information can be taken into account, among them less formal ones like oral communication. In any case, for the modern scholar the polemical texts serve as a repertoire of thought in matters of Christianity and undoubtedly reflect most of the knowledge available to Jews together with the most common Jewish reactions to Christian beliefs and doctrines. My comparison in light of the polemics not only shows how Christian compositions were transformed but also explains why and under what auspices scenes were selected or left aside.

The main text sources to be used in the following discussion are Sefer Joseph haMeqane and Sefer Nitzahon Yashan. The artistic documents to be examined are the fourteenth-century picture cycles in the Passover Haggadot from Spain and twin manuscripts produced apparently in Franconia in the late 1460s. The two manuscripts-known as the Second Nuremberg Haggadah (Jerusalem, Schocken Library, MS 24087) and the Yahuda Haggadah (Jerusalem, Israel Museum, MS 180/50) - contain consecutive biblical cycles, a rarity in Ashkenaz. ${ }^{30}$ The appearance of a consecutive cycle has indeed guided the selection of works of art for the present discussion, since only in an examination of cycles as a whole can the scenes selected and those not selected by the illuminators be taken into consideration. If relevant, however, pictures from other iconographic programs shall also be used to elucidate the subject.

Both Sefer Joseph haMeqane and Sefer Nitzahon Yashan were written in Ashkenaz. In Spain this category was rare-most texts from Spain were either reports of the disputations in Barcelona and Tortosa or writings of a primarily philosophical character. The fact that Sefer Joseph haMeqane and Sefer Nitzahon Yashan were written in Ashkenaz-probably both in France-does not necessarily mean that they or similar specimens were unknown in Spain. Scholarly contacts between Ashkenaz and Sepharad not only existed but were frequent, and numer-

\footnotetext{
${ }^{30}$ For a detailed discussion of the two Haggadot see Kogman-Appel, Die zweite Nürnberger und die Jehuda Haggada (see above, n. 3).
} 
ous Ashkenazi scholars are known to have migrated to Spain. The most prominent example is that of the family of Jacob ben Asher, a student of Meir of Rothenburg, who left Germany and settled in Toledo in 1303. Although we have no conclusive information about the distribution of such writings, we may well assume that knowledge about typology that was available through Joseph Official or the anonymous author of Sefer Nitzahon Yashan also existed in similar form among Sephardi scholars, and probably even the books themselves. Sepher Nitzahon Yashan, for example, was widely influenced by a source from the Islamic East that had reached Europe via Iberia. ${ }^{31}$ In one way or another, Jewish illuminators of both Ashkenazi and Sephardi communities were confronted with the contents of texts that were meant to strengthen their faith against Christian pressure to convert, and these texts were used by them as aids in the translation of Christian iconographic sources into a Jewish pictorial language.

\section{The Creation}

Medieval Christian depictions of the Creation (Gen. 1-2), usually appearing as a series of about seven scenes, hint at two major Christian doctrines: the Incarnation and the Trinity. It is the anthropomorphic figure of the Logos who is shown as the Creator. On the one hand, his anthropomorphic appearance implies that he would become man; on the other, the crossed nimbus identifies him as Christ and presents the Creator and the Logos as one, a theme based on John 1.1. This imagery also refers to the dogma of the Trinity. One of many examples is found in the Morgan Picture Bible of c. 1250 (New York, Pierpont Morgan Library, MS M.638, Fig. 1). ${ }^{32}$ The fact that Christian Creation cycles are so heavily loaded with allusions to Christian doctrines ${ }^{33}$ is probably the reason why in Jewish art the Creation is hardly depicted at all. A major exception is the Sarajevo Haggadah (Sarajevo, National Museum, Catalonia, c. 1350), which contains one of the richest biblical cycles ever produced by Jewish illuminators, including a sequence of eight small panels depicting the Creation (Fig. 2). ${ }^{34}$ The creation of man is depicted also in another Catalan Haggadah in London (British Library, MS Or. 2884, Fig. 3) - here as the first picture of the entire cycle. ${ }^{35}$ The creation of Eve is

${ }^{31}$ Daniel Lasker, "The Jewish Anti-Christian Polemics through the Ages" (in Hebrew), Peamim 75 (1998), 94.

${ }^{32}$ Sydney C. Cockerell, Old Testament Miniatures (London, 1969); Harvey Stahl, "The Iconographic Sources of the Old Testament Miniatures, Pierpont Morgan Library, MS 638" (Ph.D. thesis, Columbia University, New York, 1974); and idem, "Old Testament Illustration during the Reign of St. Louis: The Morgan Picture Book and the New Biblical Cycles," in Hans Belting, ed., Il medio oriente e l'occidente dell'arte del XIII secolo (Bologna, 1979), pp. 74-94.

${ }^{33}$ For patristic sources, see, for example, G. Lindeskog, Studien zum Neutestamentlichen Schöpfungsgedanken (Uppsala, 1952).

${ }^{34}$ For facsimile editions see Cecil Roth, The Sarajevo Haggadah (Belgrade, 1968); and Eugen Werber, The Sarajevo Haggadah (Belgrade, 1985). For Christian pictorial sources of the creation cycle, see Herbert Broderick, "Observations on the Creation Cycle of the Sarajevo Haggadah," Zeitschrift für Kunstgeschichte 47 (1984), 320-32.

${ }^{35}$ For more information on this manuscript, see Bezalel Narkiss, Alisa Cohen-Mushlin, and Anat Tcherikover, Hebrew Illuminated Manuscripts in the British Isles, 1: Spanish and Portuguese Manuscripts (Jerusalem, 1982), pp. 58-67. For a discussion of the Christian pictorial sources, see KogmanAppel, "Goldene Haggada" (see above, n. 2). 
known from a depiction in the same manuscript (fol. $2 \mathrm{r}$ ), and a parallel is found in the Golden Haggadah, also preserved in London (British Library, MS Add. 27210 , fol. $2 v) .^{36}$ The two manuscripts are iconographically closely related, though very different in style. The Golden Haggadah is believed to have been produced around $1320,,^{37}$ Or. 2884 around $1350 .{ }^{38}$ These pictures were modeled after Christian counterparts of primarily Western origin. The iconography of the creation of Eve, for example, has numerous parallels in works from late antiquity onward.

It is not surprising that an anthropomorphic figure of the Lord is never included in the Jewish manuscripts. An absolute taboo on the figurative depiction of God, on the basis of the Second Commandment, can easily explain this omission. ${ }^{39} \mathrm{~A}$ few remarks from Jewish polemical writings concerning the Incarnation and the Trinity, however, will further elucidate this taboo, not only with regard to the Second Commandment, but also in connection with Jewish rejection of Christian dogma. ${ }^{40}$

As Daniel Lasker has pointed out, it was the aspect of incarnation in trinitarian dogma that caused a vehement rejection of the latter by Jews, who otherwise do not exclude the possibility that God has a number of different aspects. It was the assumption that one aspect of God became human and that one aspect of the Trinity was causative of another that made the Christian idea unacceptable to Jews. ${ }^{41}$ Whereas the incarnation of Christ was a central theme in the Christian faith and the only way out of mankind's suffering caused by Original Sin, ${ }^{42}$ Jewish scholars argued that human existence was too humiliating to be associated with God, who in any case would have sufficient power to save mankind without becoming human..$^{43}$ God's incarnation would imply corporeality, a contradiction since the Christians themselves accepted the principle of God's incorporeality. ${ }^{44}$

Jewish scholars also discussed the Christian belief that Christ was the only persona of the Trinity who became human, a principle that was rejected by them as illogical. ${ }^{45}$ The cross-nimbed anthropomorphic figure of the Lord in Christian depictions of the Creation mirrors all these beliefs: it is the Logos who performs the Creation, not God the Father; God and Christ are shown as one, and the latter would become human, as indicated by his anthropomorphic appearance in scenes that occur prior to his incarnation.

\footnotetext{
${ }^{36}$ Narkiss, Golden Haggadah (see above, n. 1), and his recent Golden Haggadab (London, 1997); and Kogman-Appel, "Goldene Haggada."

${ }^{37}$ Narkiss, Golden Haggadah.

${ }^{38}$ Narkiss, British Isles, pp. 67-78. Because of the iconographic relation, Narkiss entitled the manuscript "Sister" Haggadah; for a discussion of this name see Kogman-Appel, "Picture Cycles" (see above, n. 5), p. 452, n. 9.

${ }^{39}$ Ellen S. Saltman, "The 'Forbidden Image' in Jewish Art," Journal of Jewish Art 8 (1981), 42-53.

${ }^{40}$ For the most exhaustive discussion of Jewish approaches toward these two dogmas, see Lasker, Philosophical Polemics (see above, n. 23), chaps. 4 and 5. Some material is also collected by TrautnerKromann, Shield and Sword (see above, n. 11).

${ }^{41}$ Lasker, Philosophical Polemics, p. 105 with sources.

${ }^{42}$ For sources see Lasker, Philosophical Polemics, p. 107.

${ }^{43}$ Sefer haBrit (see above, n. 14), p. 29; see also Lasker, Philosophical Polemics, p. 107.

${ }^{44}$ Lasker, Philosophical Polemics, pp. 109-10 with sources.

${ }^{45}$ For sources see Lasker, Philosophical Polemics, p. 121.
} 
Aus rechtlichen Gründen steht diese Abbildung nicht im Open Access zur Verfügung

1. Morgan Picture Bible. New York, Pierpont Morgan Library, MS M.638, fol. 1v (France, c. 1250). From top left: the creation of the world, the creation of creatures and of man, the creation of Eve, Adam and Eve eating the forbidden fruit. (All photographs reproduced by permission.) 
Aus rechtlichen Gründen steht diese Abbildung nicht im

Open Access zur Verfügung

2. Sarajevo Haggadah, fol. 1v. Sarajevo, National Museum (Catalonia, c. 1350). From top right: primordial chaos, the creation of light, the creation of the firmament, the creation of vegetation.

(From Cecil Roth, The Sarajevo Haggadab [Belgrade, 1968]) 


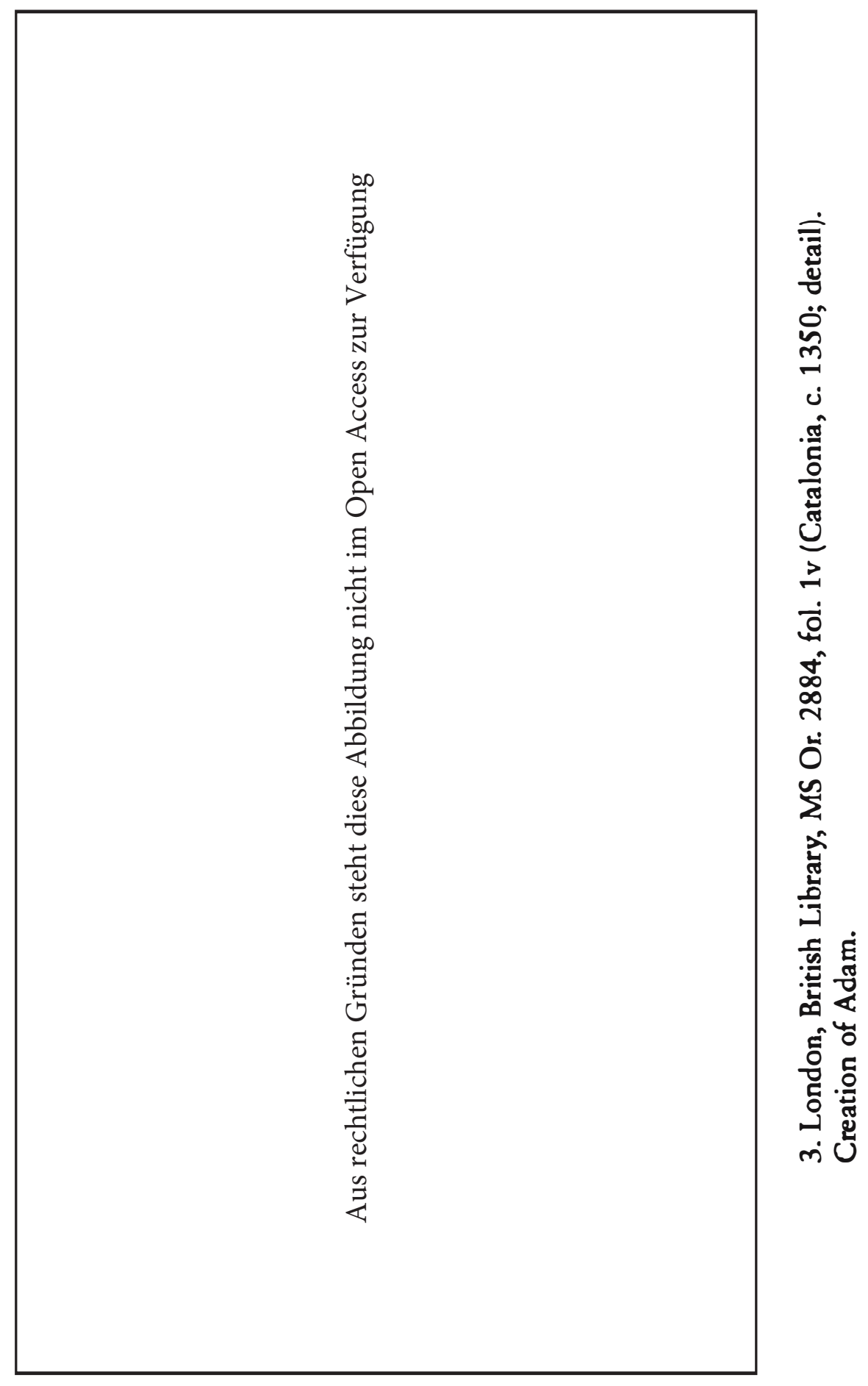


God's human appearance led to another argument in the polemical writings. Gen. 1.26- "Let us make human beings in our image, after our likeness"-was interpreted in Christian commentaries as supporting the dogmas of the Trinity and of the Incarnation. "Let us make," in the plural, would mean that God turned to the other personae of the Trinity, ${ }^{46}$ and "human beings in our image, after our likeness" would imply that God had a human appearance. ${ }^{47}$ The anonymous author of Sefer Nitzahon Yashan states, "'Let us make man' (Gen. 1.26). Answer the apostates: the Holy One, blessed be he, told the earth, Let us make man between the two of us; you contribute your share-dust, and I my share-spirit. Indeed, scripture (Gen. 1.27) goes on to explain, 'and the Lord God formed man of the dust of the ground'-this came from the earth - 'and he breathed into his nostrils the breath of life'-this is the spirit from the Holy One, blessed be he. This, then, is the meaning of 'in our image, after our likeness' (Gen. 1.26): dust in your image after your likeness, and spirit in my image after my likeness." ${ }^{48}$

Jacob ben Reuben discusses another interpretation. In his argumentation both issues are dealt with: the plural of "let us make," on the one hand, and "in our image," indicating God's anthropomorphic appearance, on the other. ${ }^{49}$ The Jewish disputant first develops the argument that the use of the plural form does not necessarily imply three beings and that the use of plurals for singular persons occurs commonly in the Bible. Finally he argues that if God is omnipotent, he needs no helpers, and, vice versa, God's needing assistance would imply a limitation of his divine powers. As to the notion of God's anthropomorphic appearance, Jacob asserts that the Hebrew text says, not "in our image," but rather "as our image." This means that man possesses a threefold soul: he grows and recreates like plants; he moves like animals; and he has the ability to discern between right and wrong. In this last quality he is close to the heavenly creatures. $\mathrm{He}$ possesses wisdom, knowledge, and rationality. ${ }^{50}$

Joseph Kimhi in Sefer haBrit interprets the plural of "let us make" as the four elements, fire, wind (the upper elements), dust, and water (the lower elements). God gave them the ability to bring forth things such as grass, plants, fish, etc., as recorded in Gen. 1.12: "the earth produced growing things: plants"; and Gen. 1.11: "let the earth produce growing things." ${ }^{51}$ Joseph Official brings up the heavenly court: " 'Let us make human beings (Gen. 1.26)', the heretics claim that there are many. His answer: 'and God created' (Gen. 1.27); it is not written 'they created', another interpretation according to Rashi: 'it was the divine measure to consult his heavenly court.' " A few paragraphs later we read: "[The heretic] said: if so, why does it read: 'let us make'? He [the Jew] said: he consulted his angels: 'the issue has been determined by the watchers and the sentence pronounced by

${ }^{46}$ For example, Peter Chrysologus, Sermo 131.12, ed. Alexander Olivar, Corpus Christianorum, Series Latina, 24B (Turnhout, 1982), p. 809; Bede, In Genesim 1.1.26, ed. Charles W. Jones, Corpus Christianorum, Series Latina, 118A (Turnhout, 1967), p. 25; and Isidore of Seville, De fide Catholica 1.3.5, PL 83:445.

47 Ambrose, Hexaemeron 6, PL 14:259-60.

${ }^{48}$ Sefer Nitzahon Yashan (see above, n. 22), pp. 42-43, trans. Berger.

49 The Christian position is reported in Milhamot haShem (see above, n. 18), p. 43.

${ }^{50}$ Milhamot haShem, pp. 44-46.

${ }^{51}$ Sefer haBrit, p. 32. 
the holy ones' (Dan. 4.14) and about this it is written (Isa. 44.26): 'I confirm my servants' prophecies and bring about my messengers' plans.' " 52

Rashi's explanation either directly or through the words of Joseph Official might have had some impact on the depiction of the creation of the first man in Or. 2884: the picture (Fig. 3) illustrates, not Gen. 1.27, but Gen. 2.7: "The Lord God formed a human being from the dust of the ground and breathed into his nostrils the breath of life, so that he became a living creature."

The first man appears in the center of the composition, while two kneeling angels appear on either side, touching the man's hands, and a standing angel to his left caresses his head. Ursula Schubert suggested that this iconography, which is unique and possesses no parallels in either Christian or Jewish art, reflects a rabbinic version of the tripartite anthropology. ${ }^{53}$ According to Schubert's view, this composition is a modification of a common Western iconographic formula. In the Cotton Genesis (London, British Library, MS Cotton Otho B.VI) the various acts of creation take place in the presence of an increasing number of angels. ${ }^{54}$ The angels of the Cotton imagery, which also includes the anthropomorphic figure of the Lord, were copied later in numerous Western cycles. ${ }^{55}$ The composition of Or. 2884, however, modifies the Christian formula. It omits the figure of the Lord and seems to emphasize rabbinic themes. More specifically, the idea of angel assistants as an interpretation of Gen. 1.26, when placed in the context of the refutation of the Christian dogma of the Trinity (as discussed in Sefer Joseph haMeqane), might have inspired the illuminator of Or. 2884 in his modification of a Christian pictorial source. The angels actively take part in the creation of man

\footnotetext{
${ }^{52}$ Sefer Joseph haMeqane, pp. 31-32, my translation. Rashi's interpretation is based on an older discussion on this question, Genesis Rabbah 8 on Gen. 1.26, ed. Jacob Neusner, Genesis Rabbah: The Judaic Commentary to the Book of Genesis. A New American Translation, 3 vols. (Atlanta, 1985), 1:73-87. The idea of God's consulting the angels is based on Rashi's commentary on Genesis.

${ }^{53}$ Ursula Schubert, "Die Erschaffung Adams in einer spanischen Haggadah-Handschrift des 14. Jahrhunderts (Br. Mus. Or. 2884) und ihre spätantike jüdische Bildvorlage,” Kairos 18 (1976), 21317.

${ }^{54}$ A copy of the Cotton depiction of the creation of the plants prepared prior to the burning of the manuscript is preserved in Paris, Bibliothèque nationale de France, MS fr. 9530, fol. 32r; see Kurt Weitzmann and Herbert L. Kessler, The Cotton Genesis, British Library Codex Cotton Otho B. VI (Princeton, N.J., 1986), pp. 49-50, fig. 7.

${ }^{55}$ A direct copy is found in the mosaics of San Marco in Venice; see Otto Demus, The Mosaics of San Marco in Venice (Chicago, 1984), figs. 107, 109-10, 112-14, and 116-17. Other-modifiedexamples are found in Carolingian manuscripts of the Bible from the ninth century, for example, London, British Library, MS Add. 10546, fol. $5 \mathrm{v}$ (see Herbert L. Kessler, The Illustrated Bibles from Tours [Princeton, N.J., 1977], pl. 1); in the ivory antependium, c. 1180, in the cathedral of Salerno (see Robert Bergman, The Salerno Ivories: Ars sacra from Medieval Amalfi [Cambridge, Mass., 1980], figs. 2 and 3); and the Millstatt Genesis, from Salzburg or Carinthia, c. 1180-1200, now Klagenfurt, Kärtner Landesarchiv, 6/19, fols. 6r and 9v (see Alfred Kracher, Millstätter Genesis und Physiologus Handschrift [Graz, 1967]). See also Weitzmann and Kessler, Cotton Genesis, pp. 52-53. This is not the place to elaborate on the discussion on Weitzmann's methodology or the "Cotton Genesis recension." Even for those scholars-like Schubert-who accept Weitzmann's recension theory, it is clear that the present formulation in Or. 2884 is a highly modified one in comparison with the Cotton example. As to my own views on the recension question see my "Sarajevo-Haggada" (see above, $\mathrm{n}$. 2).
} 
and are not placed in the background to leave space for the anthropomorphic figure of God, as in Christian counterparts.

It is significant that in the Ashkenazi Second Nuremberg and Yahuda Haggadot the theme of the Creation is not dealt with at all. The cycle of the Second Nuremberg Haggadah begins with a depiction of the temptation of Adam and Eve (fol. $30 \mathrm{v})$ and that of the Yahuda Haggadah with the rabbinic motif of Abraham's being thrown into the furnace of Nimrod (fol. 29v), an event that was caused by Abraham's faith in one God, whom he "knew at the age of three," and his rejection of Nimrod's idolatry. ${ }^{56}$ The starting point of the cycle of the Yahuda Haggadah is therefore a clear statement of the Jewish view of the one God.

\section{The Tower of Babel}

Both the Golden Haggadah (Fig. 4) and Or. 2884 (fol. 3v) contain a depiction of the building of the Tower of Babel. Following a common Christian compositional scheme, there is an additional midrashic motif of the people killing each other at the site of the tower. ${ }^{57}$ The interpolation of a midrashic motif was one of the methods of translating a Christian iconographic formula. However, the illuminators of the Golden Haggadah and Or. 2884, as well as their common model, ${ }^{58}$ might have been further inspired by a statement of Joseph Kara (c. 1070-1140), a disciple of Rashi, cited in a text added to Kimhi's Sefer haBrit: 59 "And the Christian also asked: Why did they hang that man? The learned Rabbi Joseph Kara, blessed be his memory, answered: because of the generation of division that built the tower, the Lord descended to view the tower, and he said: why will they rise up to heaven? I have already given them the earth as [their] domain. Therefore, he tore down the tower and slew them. And likewise, when Jesus came and said that he was God, they said: what do you want with our earth? Is not heaven yours? It is as David says: the heavens belong to the Lord (Ps. 117.16). Therefore they raised him up to elevate him to heaven, since they thought he would return to his domain and [thus] he was hanged." ${ }^{60}$ The imagery shows people being killed, although not by God, but by one another. The Midrash states, however, that God caused the killing.

\section{Melchizedek}

Following the events of Genesis further, I note that no Jewish cycle ever depicted the meeting between Abraham and Melchizedek. Gen. 14.17-20 reports that, after Abraham's victory over Kedorlaomer and his allies, Melchizedek went to

\footnotetext{
${ }^{56}$ For sources see Kogman-Appel, Die zweite Nürnberger und die Jehuda Haggada (see above, n. 3), pp. 63-69.

57 Genesis Rabbah 38.10, 2:53.

${ }^{58}$ For the relationship of the two manuscripts to their hypothetically assumed common model see Narkiss, British Isles (see above, n. 35), p. 77.

${ }^{59}$ For more information on the text, see Trautner-Kromann, Shield and Sword (see above, n. 11), p. 84 .

${ }^{60}$ Sefer haBrit (see above, n. 14), p. 57, my translation.
} 
Aus rechtlichen Gründen steht diese Abbildung nicht im Open Access zur Verfügung

4. Golden Haggadah. London, British Library, MS Add. 27210, fol. 3r (Catalonia, c. 1320). From top right: Noah's nakedness, the Tower of Babel, Abraham thrown into the fiery furnace, and Abraham's hospitality. 
meet him. Verses 18-20 state: "Then the king of Salem, Melchizedek, brought bread and wine. He was the priest of God most high, and he pronounced his blessing on Abram .... and he gave him the tithe of all." The figure of Melchizedek, the priest bringing bread and wine before Abraham, grew into a major representation of Christian priesthood, and the event as such became a type of the Eucharist. Thus the fifth-century mosaic in the Church of Santa Maria Maggiore in Rome $^{61}$ (Fig. 5) emphasizes the figure of Melchizedek and places the scene with him next to the altar area of the church in order to underline its significance in the context of the Eucharist. In later medieval art the imagery became more and more typological (Figs. 6 and 7). Melchizedek's identification as the prototype of the Christian priest was expressed by early Fathers, ${ }^{62}$ and as a consequence the Jewish commentators of the talmudic period abandoned and ignored the figure of Melchizedek, who in earlier sources was still identified with the figure of Shem, a prominent prototype of Jewish scholarship. ${ }^{63}$ In the polemic texts of the Middle Ages, the identification of Melchizedek as the prototype of Christian priesthood was brought up again. Both the Sefer Joseph haMegane and Sefer Nitzahon Yashan deal with the Christian argument that the meeting between Melchizedek and Abraham is to be understood as a prefiguration of the Eucharist. Joseph Official states, "A monk asked Rabbi Joseph: 'and Melchizedek brought forth bread and wine (Gen. 14.18)....' Why did he bring bread and wine before anything else? And he told him that this refers to the sacrament of bread and wine. I told him: who was the priest and who gave the tithe to whom? He said: Melchizedek was the priest and Abraham gave him the tithe of all. I told him: Where do we find Melchizedek's priesthood? We do not learn about his service anywhere, but Abraham was a priest, as it is written in the Psalm: 'The Lord said to my Lord, Sit at my right hand, until I make your enemies your footstool' (Ps. 110.1). This refers to Amraphel and his friends; ${ }^{64}$ there it says: you are a priest of the most high God, following Melchizedek: 'you are a priest forever after the order of Melchizedek' (Ps. 110.4) and we found that he offered offerings-according to the account on Mount Moriah - the ram and a number of offerings he offered and therefore the king of Salem brought forth bread and wine in order to give him the tenth of the bread and the wine." 65

The author of Sefer Nitzahon Yashan argues differently: “'Melchizedek king

${ }^{61}$ Heinrich Karpp, Die frühchristlichen und mittelalterlichen Mosaiken von Santa Maria Maggiore (Baden-Baden, 1966); and Beat Brent, Die frühchristlichen Mosaike in Santa Maria Maggiore (Wiesbaden, 1976).

${ }^{62}$ It goes back to Heb. 7.1-3 and appears later, for example, in Augustine, De civitate Dei 16.22, ed. Bernhard Dombart and Alfons Kalb, Corpus Christianorum, Series Latina, 48 (Turnhout, 1955), p. 524, or Cyprian, Epistulae 63.4, ed. G. F. Diercks, Corpus Christianorum, Series Latina, 3C (Turnhout, 1996), pp. 392-94.

${ }^{63}$ Targum Pseudojonathan on Gen. 14.18; Babylonian Talmud Nedarim 32b. Marcel Simon has demonstrated this process; see "Melchisédech dans la polémique entre Juifs et Chrétiens et dans la légende," Revue d'histoire et de philosophie religieuses (1937), pp. 58-93, repr. in Marcel Simon, Recherches d'histoire iudéo-chrétien, Etudes Juives 6 (Paris, 1962), pp. 101-26.

${ }^{64}$ Following the interpretations in the Babylonian Talmud Nedarim 32b and Midrash on Ps. 101.1 (Rashi and Ibn Ezra); see Rosenthal's edition of Sefer Joseph haMeqane (see above, n. 21), p. 40, n. 3.

os Sefer Joseph haMeqane, pp. 39-40, my translation. 
Aus rechtlichen Gründen steht diese Abbildung nicht im Open Access zur Verfügung

5. Santa Maria Maggiore, Rom, c. 432-35, Nave Mosaic, Melchizedek meeting Abraham (Photograph: Alinari/Art Resource, New York.)

of Salem brought forth bread and wine, and he was the priest of the most high God (Gen. 14.18).' The heretics say that this refers to Jesus: the bread refers to his body and the wine to his spilled blood. His body, moreover, was, as it were, eaten up and tormented. Therefore, they ask what Melchizedek hinted to Abra-ham by giving him bread and wine. The answer is that he hinted to him that his children would eventually sacrifice libations and meal offerings. " 66

Jewish scholars and, through their writings, Jewish miniaturists were therefore well aware of the meaning of Melchizedek's story in Christianity. Thus the scene, well known from various Christian pictorial sources, was not adopted by Jewish artists. It was too heavily loaded with Christological meaning and, given the rab- 
Aus rechtlichen Gründen steht diese Abbildung nicht im Open Access zur Verfügung

6. Morgan Picture Bible. New York, Pierpont Morgan Library, MS M.638, fol. 3v (France, c. 1250). Abraham and Melchizedek. 
Aus rechtlichen Gründen steht diese Abbildung nicht im Open Access zur Verfügung

7. Klosterneuburg, Abbey Church, Altarpiece by Nicholas of Verdun (1180; detail). Melchizedek.

bis' lack of interest in the figure, could not have easily been translated into a Jewish pictorial language.

\section{Abraham and Isaac}

Abraham receiving the three angels and bowing down before them was a popular theme in Christian art and bears a clear allusion to the Trinity. ${ }^{67}$ Jewish polemicists were aware of the Christian interpretation, ${ }^{68}$ and it was discussed by Joseph Kimhi in Sefer baBrit: "The heretic said: I shall show you the trinity that we believe in, in the book of Moses, and you will be unable to refute it. After Abraham was being circumcised and the Lord appeared before him, as it is written: 'The Lord appeared to him by the Terebinths of Mamre, as he was sitting at the opening of his tent in the heat of the day. He looked up and saw three men' (Gen.

67 For example, Ambrose, De Abraham 1, PL 14:435.

${ }^{68}$ Explicitly reported in Milhamot haShern (see above, n. 18), p. 46. 
18.1-2). First he saw one and he prayed to three. Then he said: 'Sirs, if now I have found favor in your [singular] eyes, do not go past your servant' (verse 3). And then he said: 'Let me send for some water so you may bathe your feet; and rest under this tree, while I fetch some bread so that you may refresh yourselves' (verses 4-5), and they stayed with him and he gave them to eat and to drink. It seemed that they drank and ate. In the beginning he talked in the singular and then he saw three and talked in the plural. These are the three: the father, the son, and the spirit." Kimhi's believer criticizes the heretic's interpretation of "bowed down" as "prayer" and identifies the angels and their mission: one came to announce Isaac's birth and two came to go on to Sodom. Since they were separated, they could not possibly be three personae of one God. ${ }^{69}$ Abraham greeting the angels is indeed not depicted in any Jewish cycle.

Abraham's encounter with the messenger angels nevertheless was of major importance in the Jewish context, since they came to announce Isaac's birth. The greeting of the angels being omitted entirely, it is only the meal served by Abraham that is shown in Jewish art, and this appears in two cycles only: those of the Golden Haggadah (Fig. 4) and Or. 2884 (fol. 3v). In Christian art the appearance of the three angels seated at the table stands for the Trinity; the meal symbolizes the Eucharist, ${ }^{70}$ and the table the Christian altar. Bread and wine therefore always play a central role in this scene. The selection of the meal-which in the Golden Haggadah was clearly modeled after Christian sources-instead of the greeting, however, elucidates the Jewish viewpoint: the meal implies that the angels ate; therefore they could not be the Lord; and therefore the event does not allude to the Trinity, as is stated in the Sefer Nitzahon Yashan: "Furthermore, if he considered them the father, the son and the impure spirit, why did he give them food? Does God eat and drink? After all, in the story of Manoah it is written: 'though you detain me, I will not eat of your bread' (Judges 13.16), while here it is written: 'so do, as you have said.' And it is written: 'and he stood by them under the tree and they did eat' (Gen. 18.5-8). And if the heretic will say that he gave them to eat in order to prefigure the son's future incarnation when he will eat and drink, the answer is that in that case he should have told one of them, 'my Lord, you eat and drink, for you are the son.' Furthermore, according to their view, all three should have been one body, while these were three bodies and did not cleave together." 71

The main message of this event in the Jewish context is, as mentioned above, the announcement of Isaac's birth. This announcement begins in the text of Genesis as follows (Gen. 18.9-10): "They asked him where Sarah his wife was, and he replied, 'she is in the tent.' One of them said, 'About this time next year I shall come back to you and your wife Sarah will have a son.' Now Sarah was listening at the opening of the tent close by him." The Jewish illuminator draws the spec-

\footnotetext{
${ }^{69}$ Sefer haBrit (see above, n. 14), pp. 50-51, my translation. See also Milhamot haShem, p. 49. For further refutations see Sefer Nitzahon Yashan, p. 48.

${ }^{70}$ See Friedrich W. Deichmann, Ravenna-Geschichte und Monumente (Wiesbaden, 1969), pp. 237-38.

${ }^{71}$ Sefer Nitzahon Yashan, p. 49, trans. Berger. The argument is also hinted at briefly, among others, in Sefer haBrit.
} 
tators' attention away from the three angels at the table to the figure of Abraham, whose arm points in a clear gesture to Sarah, who is to be seen in the tent. In Christian parallels Sarah is somewhat hidden in the tent, ${ }^{72}$ and in exceptional cases not shown at all, ${ }^{73}$ and Abraham does not point at her. The literal meaning of the event, the prophesied birth of Isaac, is not the central point in Christian art; rather the focus is on the symbol of the Trinity and the archetype of the Eucharist.

A prominent Old Testament type in Christianity is the binding of Isaac. Abraham's willingness to sacrifice his son when it is God's wish and Isaac's willingness to cooperate have made of both prefigurations of Christ, who-for the sake of mankind's salvation - willingly and deliberately went up Mount Golgotha to be crucified. The sacrifice as such also stands for the Eucharist, the site on Mount Moriah for the altar, and the ram for the crucified. Finally, Isaac carrying the wood to the mount (Gen. 22.6) prefigures Jesus carrying the cross to Mount Golgotha. ${ }^{74}$ In Christian depictions of the scene the wood on Isaac's shoulders therefore frequently appears arranged crosswise (for example, in the Morgan Picture Bible, Fig. 8).

In Jewish art Isaac carrying the wood is depicted very rarely, one example appearing in the Sarajevo Haggadah (Fig. 9). The picture follows the text in Gen. 22.5-6 very literally: "And Abraham said to his young men, 'Stay here with the donkey; and I and the boy will go on ahead. We will worship there and then come back to you.' Abraham took the wood for the sacrifice and put it on his son Isaac's shoulder; and he himself carried the fire and the knife."

In a prayer book from Germany (Wrocław, University Library, MS Or. I, 1, c. 1290, Fig. 10), Abraham is shown holding Isaac by his arm, while the youth seems to hold back. No wood appears on Isaac's shoulders or on the altar in the binding scene to the right. Only on the back of the donkey, next to the servants, in the lower register do we discern some wood. Whereas in the Sarajevo Haggadah the depiction is extremely faithful to every word of Genesis, in the Wrocław prayer book the depiction departs from the biblical text. However the illuminators chose to alter the Christian model, they often kept a safe distance from any Christological connotation and any detail that might hint at Isaac as a prefiguration of Christ.

The binding of Isaac is of central meaning also in Judaism. Unlike the meeting

\footnotetext{
${ }^{72}$ In the Cotton Genesis, fol. 70r (according to Weitzmann and Kessler's reconstruction), known from a copy in Vetusta monumenta quae ad rerum Britannicarum memoriam conservandam Societas Antiquariarum Londini sumptu suo edenda curavit, 1 (London, 1767), no. v; see Weitzmann and Kessler, Cotton Genesis (see above, n. 54), fig. 216. See also a mosaic in San Marco in Venice (Demus, San Marco, 2/2, pl. 51) and the Millstatt Genesis (see above, n. 55), fol. 27r. In a mosaic in San Vitale in Ravenna, c. 540, Sarah is not hidden; instead she is shown in the opening of the tent, observing the angels' meal, but she is somewhat pushed to the side and not "included" in the scene as in the Golden Haggadah (see Friedrich W. Deichmann, Frühchristliche Bauten und Mosaiken von Ravenna, 3 [Wiesbaden, 1958], fig. 326). It is only in the earliest rendering of this event, in the Church of Santa Maria Maggiore in Rome, that Abraham is shown pointing at Sarah (see Karpp, Santa Maria Maggiore, pl. 12).

${ }^{73}$ Brussels, Bibliothèque Royale, Cod. 10175, from 1270, fol. 40.

${ }^{74}$ In patristic sources these typological motifs appear as early as the second century; for example, Melito of Sardis, In Genesim, PG 5:1216-17; Irenaeus, Contra haereses 4.5, PG 7:985; Augustine, Enarrationes in Psalmos 30, ed. Eligius Dekkers and J. Fraipont, Corpus Christianorum, Series Latina, 38 (Turnhout, 1956), p. 209; Ambrose, De Abraham 1, PL 14:446.
} 
Aus rechtlichen Gründen steht diese Abbildung nicht im Open Access zur Verfügung

8. Morgan Picture Bible. New York, Pierpont Morgan Library, MS M.638, fol. 3r (France, c. 1250). Bottom left: Isaac carrying wood to Mount Moriah and the binding of Isaac. 
Aus rechtlichen Gründen steht diese Abbildung nicht im Open Access zur Verfügung

9. Sarajevo Haggadah, fol. 7v. Sarajevo, National Museum (Catalonia, c. 1350). Top: Lot and his daughters flee

Sodom, as his wife is turned into a pillar of salt.

Bottom: Isaac and Abraham on the way to Mount

Moriah and the binding of Isaac.

(From Cecil Roth, The Sarajevo Haggadah [Belgrade, 1968].) 
Aus rechtlichen Gründen steht diese Abbildung nicht im Open Access zur Verfügung

10. Prayer Book. Wrocław, University Library, MS Or. I, 1 , fol. $46 \mathrm{v}$ (Germany, c. 1290; detail). Binding of Isaac.

of Abraham and Melchizedek, it could not be omitted because of its crucial importance in typology (although, exceptionally, the illuminator of Or. 2884 indeed did omit it). Jewish depictions of the binding of Isaac were numerous, and many of them have been analyzed in a study by Joseph Gutmann. ${ }^{75}$

In spite of the major importance of this scene in Christianity, there are hardly any pictorial elements that speak a clear typological language. The iconography of the sacrifice of Abraham usually follows a very traditional scheme: Isaac on an altar, frequently kneeling, his hands bound; Abraham holding down the youth's head, raising in his right arm a sword held back by an angel. The angel reaches out from the sky, and his other arm points at the ram stuck in the branches of a tree (for example, in the Morgan Picture Bible, Fig. 8). Visually there are no allusions to the Crucifixion, although this is a major theme in typology, as numerous texts document. ${ }^{76}$ In typological programs the binding of Isaac is often juxtaposed

${ }^{75}$ Joseph Gutmann, "The Sacrifice of Isaac in Medieval Jewish Art," Artibus et historiae 8 (1987), 67-89.

${ }^{76}$ For example, Ambrose, De Abraham 1, PL 14:446; for more sources see Heide Lenzen and Helmut Buschhausen, "Ein neues Reichsportatile des 12. Jahrhunderts," Wiener Jabrbuch für Kurstgeschichte 20 (1965), 21-73. 
with a depiction of the Crucifixion. ${ }^{77}$ Even where there is no clear visual allusion to the Crucifixion, some of the Jewish miniaturists were well aware of the strong Christological implications of their model. Most of them exchanged a knife for the sword-again in simple faithfulness to the text. Whereas the Vulgate has gladius (sword), the Hebrew text reads ma'achelet (large knife). Exceptions are the Wrocław prayer book mentioned above (Fig. 10) and another Ashkenazi prayer book in Leipzig (University Library, MS V 1102/II, fol. 66r). ${ }^{78}$ Others added various specifically Jewish elements, many of which are listed in Gutmann's study. ${ }^{79}$

The illuminators of the Golden Haggadah and Or. 2884, however, seem to have been the most concerned to avoid Christological connotations. In Or. 2884 the scene was simply omitted, which is surprising considering the fact that this was a major event in Israel's history, and we certainly would expect the story to be rendered in a pictorial cycle as rich as that of Or. 2884. The artist of the Golden Haggadah found another solution (Fig. 11). He completely altered the traditional iconography and created a composition that has no parallel in other Christian or Jewish cycles: there is no altar, probably because of the association with the Christian altar and the Eucharist. This is surprising, however, since the altar on Mount Moriah plays an important role in the Jewish tradition: Abraham's altar is identified with that of Adam, Abel, and Noah, ${ }^{80}$ and the binding took place at the site where the future Temple would be built. ${ }^{81}$ Nevertheless the artist of the Golden Haggadah omitted the altar, and Isaac lies bound on the ground. There is no wood whatsoever, not on the ground, on Isaac's shoulders, or on the donkey's back. Abraham is not standing upright, and neither of his arms is stretched out. He bows down toward Isaac on the ground holding him down, the knife in his right hand. His face is turned toward the angel. Nothing in the composition even slightly recalls anything that could parallel a Christian composition of the Isaac scene or the Crucifixion.

Given the central importance of the sacrifice of Abraham in Christian typology, it is surprising, on the one hand, not to find pictorial details in Christian art that point clearly to the typological context and, on the other, to discover that Jewish artists had little trouble in coping with the scene. The example of the Golden Haggadah is exceptional: most illuminators simply contented themselves with incorporating a few midrashic elements or following the text very closely. It is yet more surprising that the subject hardly came up in polemical writings. In Sefer Joseph haMeqane the typological connection to the Crucifixion is not mentioned at all. The Sefer Nitzahon Yashan brings up the theme; the discussion, however, concentrates on the ram and the Paschal Lamb foreshadowing Christ's sacrifice: "The heretics also say that this passage refers to the hanged one who gave his life

\footnotetext{
${ }^{77}$ For example, in the Klosterneuburg altarpiece; see Buschhausen, Verduner Altar (see above, n. 6), figs. 25-26.

${ }^{78}$ For a facsimile edition see Elias Katz, ed., Machsor Lipsiae: 68 Faksimile Tafeln der mittelalterlichen hebräischen illuminierten Handschrift aus dem Bestand der Universitätsbibliothek Leipzig (Vaduz, 1964).

79 See above, n. 75.

${ }^{80}$ Pirke de Rabbi Eliezer 31, ed. Gerald Friedländer (New York, 1981), p. 227.

${ }^{81}$ This is made clear in the Bible, 2 Chron. 3.1, and later in Josephus, Antiquitates Judaicae 1.13.
} 
Aus rechtlichen Gründen steht diese Abbildung nicht im Open Access zur Verfügung

11. Golden Haggadah. London, British Library, MS Add. 27210, fol. 4v (Catalonia, c. 1320). From top right: Lot escaping from Sodom, the binding of Isaac, Isaac blessing Jacob, and Jacob's dream. 
to atone for them, as it is written, 'And he offered it up for a burnt offering in the stead of his son' (Gen. 22.13). Similarly, they say of the paschal lamb, concerning which it is written, 'They shall take to them every man a lamb according to their father's houses' (Ex. 12.3), that it prefigures the execution of the hanged one. There are, indeed, many verses which they interpret as references to the hanged one, and they tell us: Fools, we know that the Torah was given to you and not to us; why, then, do you not perceive its nature?" 82

Despite the importance of the Abraham scene in Christian thought and art, it was not dealt with as a major subject in the polemical literature. Nor, as I have noted, did its Christological implications pose a major challenge for Jewish artists. That the scene was not problematic for Jewish artists suggests that polemical writings and discussions did indeed serve as a source of their knowledge about Christological matters: if the polemicists rarely brought up the subject, the artists similarly were not challenged by it. The illuminators of Or. 2884, who omitted the entire scene, and of the Golden Haggadah, who altered the traditional scheme entirely, are exceptions.

The Second Nuremberg (fol. 31v) and the Yahuda Haggadot (Fig. 12) include a theme that draws a further line between Jewish iconography, the Midrash, and polemical writings. Above a rather traditional depiction of the binding of Isaac, Isaac is shown again, coming down from heaven in an upside-down position. This unusual picture is accompanied-as all the scenes in the two Haggadot are-by a title: "Isaac returned glorified from the garden (of Eden) that God planted for our protection." 83

The theme that Isaac was actually killed and resurrected is a midrash. ${ }^{84} \mathrm{How}-$ ever, it is mentioned also in Sefer Nitzahon Yashan: "They also talk: Did Abraham do such a great thing when he was willing to slaughter his son pursuant to a divine command? Why, there is not an evil man in the world who would refrain from doing so if the Holy One, blessed be he, appeared to him in all his glory and told him to slaughter his son. The answer is that it was nevertheless a great thing, for he was an only son in their old age, and yet they did not hesitate or hold him back. This lack of hesitation is confirmed when we ask why Abraham did not realize that he was only being tested. After all, God had already promised him, 'For in Isaac shall seed be called to you' (Gen. 21.12), and how could he contradict his earlier promise? It must be, then, that Abraham did not stop to think the matter through at all. This last question, however, might also be answered by assuming that Abraham thought that God, who quickens the dead, would resurrect Isaac." 85

\section{Jacob and Joseph}

Some of the polemical texts discuss the Christian claim that Jacob was a deceiver. He "deceived" Laban, as told in Gen. 30, by causing the flock to bring

${ }^{82}$ Sefer Nitzahon Yashan (see above, n. 22), p. 52, trans. Berger.

${ }^{83}$ Translation of the title in the Second Nuremberg Haggadah from Bezalel Narkiss and Gabrielle Sed-Rajna, Index of Jewish Art: Iconographical Index of Hebrew Illuminated Manuscripts, 2/2: The Second Nürnberg Haggadah (Munich, 1981).

${ }^{84}$ Pirke de Rabbi Eliezer 31, p. 228.

${ }^{85}$ Sefer Nitzahon Yashan, pp. 54-55, trans. Berger. 
Aus rechtlichen Gründen steht diese Abbildung nicht im Open Access zur Verfügung

12. Yahuda Haggadah. Jerusalem, Israel Museum, MS 180/50, fol. 30v (Germany, c. 1465). Top right: Isaac returning from Paradise. 
forth striped, dotted, and dark-furred sheep and goats by putting sticks, the bark of which he had cut in strips, next to the watering troughs. In this way Jacob's part of the flock increased and made him rich. This scene is rarely, if ever, depicted in Christian art and appears only in very extensive cycles. ${ }^{86}$ Jewish cycles contain fewer scenes than the corresponding sections in late-medieval picture Bibles and Psalters; usually only the highlights of biblical history are rendered pictorially. Nevertheless, Or. 2884 includes this event (Fig. 13). Whereas the parallel cycle in the Golden Haggadah exhibits Jacob's ladder, followed immediately by the family passing the Yabbok, Or. 2884 is enriched by three further pictures dedicated to the story of Jacob and Laban's flock. This sequence includes the more popular scenes of the arrival of Jacob at the well, the patriarch feasting with Laban and Rachel (fol. 5r), and the increasing of the flocks. The inclusion of such a minor theme, only rarely depicted even in more extensive Christian cycles, can be explained by the polemicists' concern about the accusations made against Jacob, as in the following argumentation in Sefer Joseph haMeqane: "'And he went out.' The heretics say that Jacob deceived Laban. The answer is: he changed the terms. R. Joseph added: Jacob was very faithful and he had great faithfulness for Laban, but Laban deceived him, when he put the condition: 'I shall go through your flocks today, and pick out from them all the speckled and spotted cattle, and all the brown cattle among the sheep, and all the spotted and speckled goats' (Gen. 30.32) and put them at another place; 'and they will be my wages.' From here and the following we learn that the striped ones will be my wage- those who are to be born. 'And Laban said: let it be as you say.' " 87

The Joseph story is extensively depicted in Christian and Jewish cycles. Joseph being thrown into the pit and later pulled out (Gen. 37.21-28) became a prefiguration of Jesus' entombment and his resurrection. ${ }^{88}$ For some reason, however, it was not explicitly dealt with in the polemical writings. The Sefer Nitzahon Yashan brings up the general idea of Joseph's prefiguring Jesus very briefly: "The heretics say: 'And they dipped the coat in the blood' (Gen. 37.31); this story of Joseph prefigures the hanged one. For example, the fact that Joseph's mother was barren prefigures Mary, who was a virgin. The answer is: How can one draw such an analogy between the living and the dead? Joseph was not killed; they merely desired to kill him. Jesus, on the other hand, was actually hanged. If the heretic will reply that only the human part of Jesus was killed, the answer is that if this

\footnotetext{
${ }^{86}$ According to Weitzmann and Kessler's reconstruction of the Cotton Genesis (see above, n. 54), this scene must have been depicted on fol. 127v; later it appears in the Velislav Bible, Prague, University Library, Cod. XXIII C 124 (Bohemia, c. 1340), fol. 31v (K. Stejskal, Velislai Biblia picta, circa 1340 [Prague, 1970]); in the Egerton Bible, London, British Library, MS Egerton 1894 (England, fourteenth century), fol. 16v (M. R. James, Illustrations of the Book of Genesis [Oxford, 1921]); and the Padua Bible, Rovigo, Accademia dei Concordi, MS 212 (northern Italy, c. 1400), fol. 22v (Gianfranco Folena and Gian Lorenzo Mellini, Bibbia istoriata padovana della fine del trecento [Venice, 1962]).

${ }^{87}$ Sefer Joseph haMeqane (see above, n. 21), p. 41, my translation.

${ }^{88}$ Adam of St. Victor, Zyma vetus expugetur, quoted by Helmut Buschhausen, "The Klosterneuburg Altar of Nicholas of Verdun: Art, Theology and Politics," Journal of the Warburg and Courtauld Institutes 37 (1974), 13.
} 
Aus rechtlichen Gründen steht diese Abbildung nicht im Open Access zur Verfügung

13. London, British Library, MS Or. 2884, fol. 5v (Catalonia, c. 1350).

Top: Jacob increasing the flocks. Bottom: Jacob wrestling with an angel. 
is so, how did he differ from other men? In other men, too, the flesh dies while the soul goes either to paradise or to hell." ${ }^{89}$ Probably because of the relative silence of the polemicists in this matter, the subject did not raise any conflict and appears in various Jewish cycles (for example in the Golden Haggadah, Fig. 14)..$^{90}$

The story of the dreams of the baker and the butler, their interpretation, and fulfillment received more attention. According to Josephus, the baker was crucified, ${ }^{91}$ a motif followed in the Cotton Genesis ${ }^{92}$ and in a mosaic in San Marco in Venice. ${ }^{93}$ Kurt Weitzmann concluded that this iconography must have been borrowed in antiquity from an illustrated Josephus text. ${ }^{94}$ Although not shown frequently in art, the motif apparently entered Christian interpretation, as we can tell from the Jewish reactions. ${ }^{95}$ The anonymous author of the Sefer Nitzahon Yashan communicates this idea to Jewish readers and refutes it: " $O n$ the vine were three branches' (Gen. 40.10). The heretics distort this passage and refer it to the hanged one, arguing that just as the chief baker was hanged, so Jesus was hanged. Furthermore, they say, the three openwork baskets ${ }^{96}$ represent the three days that he was buried. You may answer that just as the bread of the chief baker was not seemly, so the Torah that Jesus wanted to give was not proper and seemly. Moreover, just as the chief baker was hanged and passed away from the world, so Jesus was hanged and passed away from the world." ${ }^{97}$ Given the insignificance of the theme of the crucified baker in Christian typology, it is surprising, yet significant, that there is not only no depiction of the crucified baker in Jewish art, but not a single depiction of the fulfillment of the dreams.

The conversation between the royal clerks and Joseph interpreting the dreams, on the other hand, is shown in most Jewish cycles. Either it is shown simply as an encounter, as in the Second Nuremberg (fol. 36v), the Yahuda (Fig. 15), and the Sarajevo Haggadot (fol. 13v), or it includes a pictorial rendering of the dreams, as in the Golden Haggadah (Fig. 14) and Or. 2884 (fol. 7v). However, in contradiction to the text in Gen. 40.16, only one basket is shown on the baker's head, whereas some Christian parallels exhibit all three baskets. ${ }^{98}$

${ }^{89}$ Sefer Nitzahon Yashan (see above, n. 22), p. 57, trans. Berger.

${ }^{90}$ See also Or. 2884 , fols. $6 \mathrm{v}-7 \mathrm{r}$; and the Sarajevo Haggadah, fol. $12 \mathrm{r}$.

${ }^{91}$ Antiquitates Judaicae 2.5.3.

${ }^{92}$ Fol. $85 \mathrm{r}$ (174r of the reconstructed codex); see Weitzmann and Kessler, Cotton Genesis (see above, n. 54), pp. 110-11.

${ }^{93}$ Demus, San Marco (see above, n. 55), fig. 280.

${ }^{94}$ Kurt Weitzmann, "The Question of the Influence of Jewish Pictorial Sources on Old Testament Illustration," in Herbert L. Kessler, ed., Studies in Classical and Byzantine Manuscript Illumination (Chicago, 1971), p. 89.

${ }_{95}$ Weitzmann interprets it as a type of the crucifixion of the thieves: Kurt Weitzmann, "The Genesis Mosaics and the Cotton Genesis Miniatures," in Demus, San Marco, p. 135.

${ }_{96}$ The text in Genesis also mentions three baskets on the baker's head (Gen. 40.16), interpreted by Joseph as a sign that, in three days, Pharaoh would hang the baker.

${ }_{97}$ Sefer Nitzahon Yashan, p. 58, trans. Berger.

${ }^{98}$ For example, in a mosaic in San Marco (Demus, San Marco, pl. 272) and the closely related Vienna Histoire universelle, Vienna, Österreichische Nationalbibliothek, Cod. 2576, fol. 37r, northern Italy, end of the fourteenth century (Koichi Koshi, Die Genesisminiaturen in der Wiener "Histoire universelle" (Cod. 2576) [Vienna, 1973], pp. 28-32, fig. 39). 
Aus rechtlichen Gründen steht diese Abbildung nicht im Open Access zur Verfügung

14. Golden Haggadah. London, British Library, MS Add. 27210, fol. 6v (Catalonia, c. 1320). From top right: Joseph thrown into the pit, Joseph sold to the Ismaelites, Jacob mourning, Joseph being seduced by Potiphar's wife, and Joseph interpreting the dreams of the butler and the baker. 
Aus rechtlichen Gründen steht diese Abbildung nicht im Open Access zur Verfügung

15. Yahuda Haggadah. Jerusalem, Israel Museum, MS 180/50, fol. 35v (Germany, c. 1465). Joseph interpreting dreams. 
Another typological interpretation based on Genesis appears in the description of Jacob blessing Joseph's sons with crossed hands (Gen. 48.13-14): “And Joseph took the two of them and brought them close to Israel: Ephraim on his right, that is Israel's left; and Manasseh on the left, that is Israel's right hand. Israel stretched out his right hand, and laid it on Ephraim's head, who was the younger, and laid his left hand on Manasseh's head, guiding his hands wittingly, for Manasseh was the firstborn."

The blessing was frequently associated with the cross, ${ }^{99}$ and the sixth-century depiction in the Vienna Genesis (Vienna, Österreichische Nationalbibliothek, Cod. theol. gr. 31, Fig. 16) already makes this very clear: it emphasizes the crossed arms of the patriarch, who is shown seated on a stool in a fully frontal position, instead of in his bed, as the Bible has it (Gen. 48.2). In this seated position it was easier for the artist to emphasize Jacob's crossed arms. As Wolfgang Stechow has shown, this formula became very common in medieval art, replaced only in the early modern period by other, less typological versions. ${ }^{100}$ Although a highlight of the Joseph story, the scene is omitted from the cycles of the Second Nuremberg and the Yahuda Haggadot. Whether the reason for the omission is the typological background of the scene in Christian art is not clear, since the cycles stop with the depiction of Joseph's rehabilitation and include no scene related to the brothers in Egypt.

Among the Sephardi Genesis cycles it is the Sarajevo Haggadah that omits the blessing of Ephraim and Manasse. Only Jacob's journey to Egypt (fol. 18r) and the transfer of his coffin to Canaan (fol. 19v) are shown. The Golden Haggadah (Fig. 17) and Or. 2884 (fol. 11r) do not go so far as to omit the entire scene. They do show the crossed arms but alter the compositional type. Although the frontal position of the seated patriarch was still known in late-medieval art, as the example of the Morgan Picture Bible shows (Fig. 18), ${ }^{101}$ the Jewish miniaturists chose to follow the text more faithfully. Jacob is seated in bed and is shown from the side. Although his arms are crossed, the position of the arms does not create a visual association with a cross with right angles (Fig. 17). The focus on the crossed arms, which characterizes the Christian parallels, is avoided. The Sefer Nitzabon Yashan explains the context quite clearly: " 'He crossed his hands, for Manasseh was the firstborn' (Gen. 48.14). The heretics say that he made a kind of cross with his two arms by placing one on the other, and thus he blessed him. Answer them: Therefore, 'Joseph thought it wrong and said, Not so, father (Gen. 48.17-18), it is wrong to do this'. And Jacob answered him, 'I know, my son, I know' (Gen. 48.19) that it is wrong to do this, but I was forced to cross my hands because the younger brother will be the greater and I must therefore put my right hand on his

\footnotetext{
${ }^{99}$ For example, Isidore of Seville, Questiones, PL 83:277. For other sources see Wolfgang Stechow, "Jacob Blessing the Sons of Joseph from Early Christian Times to Rembrandt," Gazette des beauxarts 23 (1943), 193-208, repr. in Joseph Gutmann, ed., No Graven Images: Studies in Art and the Hebrew Bible (New York, 1971), pp. 261-76.

100 Stechow, "Jacob."

${ }^{101}$ Another example can be found in the Pamplona Bible in Amiens, Bibliothèque municipale, MS lat. 108, Spain, c. 1200, fol. 36v; see François Bucher, The Pamplona Bibles (New Haven, Conn., 1970), pl. 92.
} 


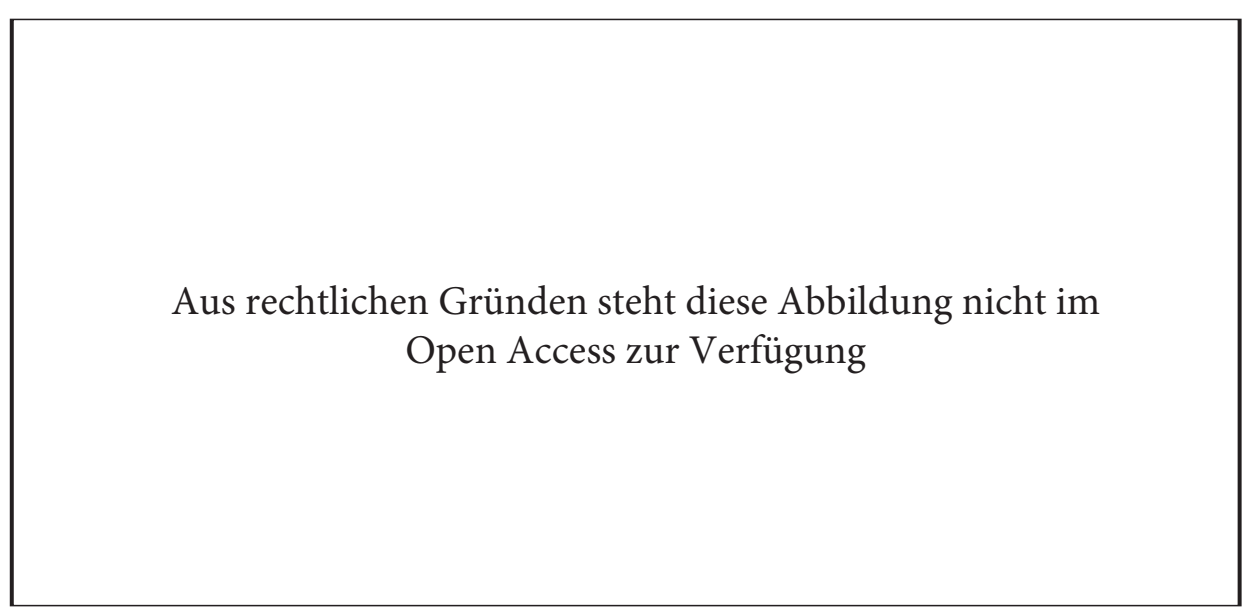

16. Vienna Genesis. Vienna, Österreichische Nationalbibliothek, Cod. theol. gr. 31, p. 45 (Byzantium, sixth century; detail). Jacob blessing Ephraim and Manasse.

head even though he is standing to my left. I did not, therefore, do it with the intention of making a cross." ${ }^{102}$ Given that interpretation, it was not necessary for Jewish artists to omit the crossing of the arms, much less the entire scene, but it was clear that miniaturists should not focus on the motif.

It should be mentioned here that in the Padua Bible produced in northern Italy around 1400 (Fig. 19), ${ }^{103} \mathrm{Jacob}$ is shown in bed as the text has it; however, he makes an extreme effort to turn his upper body toward the grandsons and the spectator. In this position, the crossed arms could be as clearly emphasized as in the other parallels. The Padua Bible belongs to the group of works of art ${ }^{104}$ that seem to have had the strongest impact on the Sephardi cycles. In addition, it is the one work of art in which the most parallels to the Sephardi cycles, especially that of the Golden Haggadah and Or. 2884, can be found.

\section{Moses}

The Book of Exodus also has many openings for typological interpretation. Christian pictorial cycles very often include a depiction of Moses' birth, reported in Exod. 2.2. Since this scene parallels the birth of Christ, although based primarily on visual associations, it became a prominent opening scene of Christian Exodus cycles. ${ }^{105}$ It appears in none of the surviving Jewish ones; instead the cycles start with various other episodes from the story of Moses.

\footnotetext{
102 Sefer Nitzahon Yashan, pp. 59-60, trans. Berger.

103 See above, n. 86.

104 As to the iconographic sources of the Padua Bibles, see Susan Arensberg-MacMillan, "The Padua Bible and the Late Medieval Biblical Picture Book” (Ph.D. diss., Johns Hopkins University, Baltimore, 1986).

${ }^{105}$ For example, in the Morgan Picture Bible (see above, n. 32), fol. 9v. The Exodus part of the Padua Bible is preserved in London, British Library, MS Add. 15277; see fol. 1v.
} 
Aus rechtlichen Gründen steht diese Abbildung nicht im Open Access zur Verfügung

17. Golden Haggadah. London, British Library, MS Add. 27210, fol. 8v (Catalonia, c. 1320). From top right: Jacob before Pharaoh, Jacob blessing Ephraim and Manasse, mourning over Jacob, and Israelite infants cast into the river. 
Aus rechtlichen Gründen steht diese Abbildung nicht im Open Access zur Verfügung

18. Morgan Picture Bible. New York, Pierpont Morgan Library, MS M.638, fol. 7r (France, c. 1250). Top left: Jacob blessing Ephraim and Manasse. 


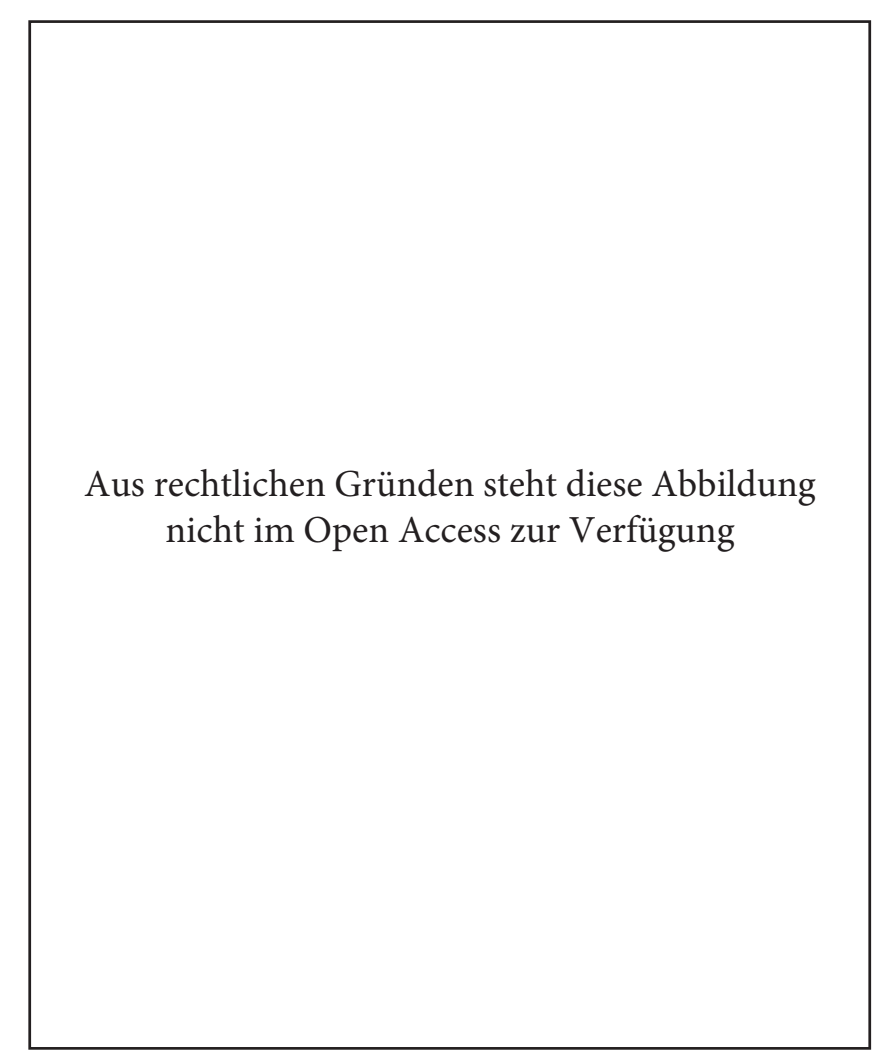

19. Padua Bible. Rovigo, Accademia dei Concordi, MS 212, fol. 36v (northern Italy, c. 1400; detail). Jacob blessing Ephraim and Manasse. (From Gianfranco Folena and Gian Lorenzo Mellini, Bibbia istoriata padovana della fine del trecento [Venice, 1962], pl. 72.)

A major keystone of typological interpretation was the striking of the doorposts of the Israelite houses with the blood of the Passover lamb (Exod. 12.22). According to Christian interpretation, the blood was applied in the shape of a $T$. Ezod. 9.4 reads: "And the Lord said to him, Go through the midst of the city, through the midst of Jerusalem, and set a 'taw'106 on the forehead of the men that groan and cry for all the abominations practiced there."

The context is a vision about the punishment of Jerusalem for its sins. The righteous, signed with the Hebrew letter taw - the form of which in biblical times recalled a cross shape-were to be saved. Jerome refers to the letter taw as signum. ${ }^{107}$ In Greek it is understood as tau and in Latin as $t$. Because of the cross shape of $t$, Tertullian, for example, understood it as a cross. ${ }^{108}$ The chosen people, whose firstborns were not to be killed, became those who believed in the cross. This was visualized, for example, in the Klosterneuburg altarpiece (Fig. 20). Since this is one of the basic events in the Exodus story, on which the Haggadah focuses, this scene was not necessarily omitted as such. It was rendered following the text, as in the Second Nuremberg (fol. 17v) and the Yahuda (Fig. 21) Haggadot, and

${ }_{106}$ The King James Version reads "mark" here, while The Oxford Study Bible (Oxford, 1992) reads "cross."

107 Quaestiones Hebraicae in Librum Regum 3, PL 23:1366.

${ }^{108}$ Adversus Marcionem 3.22.6, ed. Eligius Dekkers et al., Corpus Christianorum, Series Latina, 1 (Tumhout, 1954), p. 539. 
Aus rechtlichen Gründen steht diese Abbildung nicht im Open Access zur Verfügung

20. Klosterneuburg, Abbey Church, Altarpiece by Nicholas of Verdun (1180; detail). Striking of doorposts with blood.

in some cases enriched by midrashic insertions, as in the Rylands Haggadah (Manchester, John Rylands University Library, MS heb. 6, Fig. 22) and a closely related Haggadah in London (British Library, MS Or. 1404, fol. 7v). ${ }^{109}$ The latter two manuscripts were produced in Catalonia in the fourteenth century, and their cycles contain Exodus scenes only. The Golden Haggadah, Or. 2884, and the Sarajevo Haggadah omit the event. Sefer Nitzabon Yashan clarifies the Jewish point of view: " 'And apply [the blood] to the lintel and to the two doorposts' (Ex. 12.22). They say that the blood in these three places formed a cross and that is why they were saved. The answer is that this is not the meaning. What God meant, rather, was that he would judge the Jews innocent when he would see the three dabs of blood on the entrance, for they symbolize the blood of Abraham's circumcision, of the binding of Isaac when Abraham was willing to slaughter his son and of the paschal lamb. Indeed, it is these three types of blood that are also referred to in the verse, 'and I saw you polluted in your blood'-one-'and I said to you, in your blood,

${ }^{109}$ Kogman-Appel, "Rylands Haggadah" (see above, n. 2). 
Aus rechtlichen Gründen steht diese Abbildung nicht im Open Access zur Verfügung

21. Yahuda Haggadah. Jerusalem, Israel Museum, MS 180/50, fol. 16v (Germany, c. 1465). Striking of doorposts with blood. 
Aus rechtlichen Gründen steht diese Abbildung nicht im Open Access zur Verfügung

22. Rylands Haggadah. Manchester, John Rylands University Library, MS heb. 6, fol. 19v (Catalonia, c. 1350).

Striking of doorposts with blood and preparations for Passover.

live!'-two-'and I said to you, in your blood, live!'-three (Ez. 16.6). 'And apply ... 'It was because God knew that people would err by following the cross that he did not command that blood be placed on the threshold. Thus, he omitted the fourth corner, so that there would be no cross here and no crucifixion." 110

The Fathers frequently explained the parallels between the crossing of the Red Sea and baptism, whether Christ's baptism in the river Jordan by John the Baptist or the Christian sacrament in general. ${ }^{111}$ Typological programs, therefore, frequently juxtapose the two scenes, as, for example, in the Klosterneuburg altar-

110 Sefer Nitzahon Yashan, p. 64, trans. Berger.

11 See 1 Cor. 10.1; Augustine, Sermo 213.8, PL 38:1064-65; Quodvultdeus, De cataclysmo 3, ed. R. Braun, Corpus Christianorum, Series Latina, 60 (Turnhout, 1976), p. 409; and Ambrose, De sacramentis 1.21-22, PL 16:442. 
piece. ${ }^{112}$ Joseph Official uses this theme to demonstrate the Jewish point of view concerning baptism: "But the Israelites had marched through the sea on dry ground ... (Ex. 14.29). A priest asked Rabbi Joseph: What sign was it, when the waters were parted and Israel passed through their midst? I said to him: What do you say [it was]? He said to me: It is a sign of obliteration. I told him: You have spoken truly; those who crossed on the dry land and were not polluted by water were saved, while those who did not walk on the dry land and were polluted by water went under. He said to me: If that is true, why were they then parted? $\mathrm{He}$ [God] should have caused them to walk across the water. I told him: That is a sign that we must live among you, but we must not be polluted by the water. Afterward, he asked me about the interpretation and I told him: If he had not parted the waters, it would have been difficult for them to get across, as there were high waves." 113

The crossing of the Red Sea, a highlight of the Exodus story and the major theme of the Haggadah, is never omitted from Jewish cycles. Moreover, they all contain the drowning Egyptians. On one hand, the destruction of Pharaoh's army shows Israel's salvation through the intervention of God, but its sometimes very prominent position in the cycles - at times as a separate picture on its own, and not as part of the crossing of the sea by the Israelites-may also imply that baptism may have negative consequences for the soul, as expressed by the polemicists. In Christian cycles the drowning of the Egyptians is considered only a minor event; the focus is on the salvation of the Israelites. Although the drowning Egyptians are frequently included as part of a composition showing the crossing of the sea, very rarely is an entire Christian composition devoted to it. ${ }^{114}$

The foregoing discussion sheds some light on the ways Jewish illuminators coped with the Christological content of the Christian pictorial sources they used. Knowledge of Christian matters could be gained in various ways, with the contemporary polemical literature as the most substantial source for the modern scholar. Jews were confronted with Christian doctrine simply by living in Christian environments and, of course, through forced sermons. The polemical texts, however, are not only the sole written source that reflects various other-oral-means of communication; they also functioned as the main medium of rabbinical reactions to Christian doctrine and of scholarly guidance for believers in coping with that doctrine. Knowledge about what should be avoided in a Jewish picture cycle could be gained through the contacts of everyday life, through rabbinic sermons meant as reaction to Christian pressure, and through polemical writings. Guidance was needed in order to handle Christian models and to translate them into a Jewish pictorial language. The greater the impact of Christian pictorial sources on Jewish iconography, the stronger the need for an awareness of Christological views of

112 Buschhausen, Verduner Altar (see above, n. 6), figs. 13 and 14.

${ }^{113}$ Sefer Joseph haMeqane (see above, n. 21), p. 47; translation from Trautner-Kromann, Shield and Sword (see above, n. 11), p. 97. Trautner-Kromann believes Joseph Official's argumentation to be ironic, even humorous, the "real" interpretation being only the last part.

${ }^{114}$ For example, in the Pamplona Bible in Amiens (see above, n. 101), fol. 49r; see Bucher, Pamplona Bibles, pl. 119. 
the Old Testament and typology. As to the use of rabbinic commentary, for example, the Midrash or Rashi, which hitherto was considered to be the most significant characteristic of Jewish iconography, it appears that, when Christian pictorial sources were extensively used, the selection of midrashic themes in the picture cycles was guided by the discussion in the polemics.

The Sephardi cycles relied heavily on Christian counterparts. Therefore their creators were greatly concerned with Christological interpretation as it was discussed in the polemical material. The surviving polemical texts are our best source for the Christian themes that medieval Jewry was confronted with, aware of, and reacted to. The Ashkenazi cycles discussed here are less indebted to Christian pictorial sources than are their Sephardic counterparts. ${ }^{115}$ Some, but not all, compositions reflect traditional types, common in Christian Old Testament iconography, though many are unique. The "translation process" was less complex, and the Midrash was used not only for translation but also-even primarily-for the invention of original Jewish iconographic themes. The Midrash played a major role in these cycles. ${ }^{116}$ Thus, as we have seen, the illuminators of the Second Nuremberg and the Yahuda Haggadot were little influenced by the information provided by the polemical commentators.

Although Jewish illuminators apparently were confronted with the category of texts that is usually referred to as "polemical writings," very little in the way of real polemics was expressed pictorially. ${ }^{117}$ Polemical iconography is very subtle; its place is usually the marginal decoration of manuscripts and hardly ever a biblical cycle. In most cases polemical assertions discussed in the texts are not expressed explicitly in the imagery. Jewish illuminators coped with Christianity through avoidance; the knowledge gained from polemical writings guided the illuminators in the avoidance of iconographic details of specific Christological character. Explicitly anti-Christian themes played only a minor role in Jewish biblical picture cycles.

${ }^{115}$ Kogman-Appel, Die zweite Nürnberger und die Jehuda Haggada (see above, n. 3), chap. 5.

${ }^{116}$ Ibid.

${ }^{117}$ Kurt Schubert, "Wikkuach-Thematik in den Illustrationen hebräischer Handschriften," Jewish Art 12-13 (1986-87), 247-56.

Katrin Kogman-Appel teaches art history at Ben-Gurion University of the Negev, Beer Sheva, Israel 84105 (e-mail: katrin@bgumail.bgu.ac.il). 